Between Political Emancipation and Creole Hegemony: Viscardo's

Letter to the Spanish Americans (c. 1791)

Humberto Rafael Núñez-Faraco

Department of Spanish, Portuguese \& Latin American Studies

University College London, $U K$

Tel. 02076794332

Email: h.faraco@ucl.ac.uk 


\title{
Between Political Emancipation and Creole Hegemony: Viscardo's Letter to the Spanish Americans (c. 1791)
}

\author{
Viscardo's Letter to the Spanish Americans inaugurates a tradition of \\ nonconformist political writing against Spanish colonial rule during the second \\ half of the eighteenth century, a period characterised by the Crown's attempt to \\ reorganise several aspects of the colonial administration. As an ex-Jesuit living in \\ exile after the expulsion of the Society of Jesus from all Spanish territories in \\ 1767 , Viscardo had a political as much as a personal motive in designing a \\ project that would cut the colonial ties between Spain and the New World. His \\ plans for emancipation included the instauration of a monarchical form of \\ government, but his design was out of touch with reality and would have hardly \\ been taken seriously by the inhabitants had a British-backed expeditionary force \\ reached the coasts of Chile and Peru, as he had planned. While Viscardo's Letter \\ may have stirred a sense of creole patriotism some years after his death, the \\ political scruples of the ancien regime based on social privileges and racial \\ distinctions were too strong to be dismantled by mere ideals of freedom, justice \\ and equality. Thus, effective political participation was restricted to the creole \\ elite, whom Viscardo saw as the legitimate guarantor of social order and \\ economic prosperity.
}

Keywords: Bourbon reforms, colonialism, natural rights, political emancipation, racial heterogeneity, Viscardo y Guzmán

\section{Introduction}

Viscardo's Letter to the Spanish Americans inaugurates a tradition of nonconformist political writing against Spanish colonial rule during the second half of the eighteenth century, a period characterised by the Crown's attempt to reorganise several aspects of the colonial administration in order to fulfil its economic potential. The Bourbon reforms implemented by Charles III, which sought a stricter and more demanding 
taxation system, created much discontent among the colonial population and were directly responsible for some of the most powerful peasant and indigenous rebellions witnessed during those years, such as the Tupac Amaru rebellion in the viceroyalty of Peru and the Comunero revolt in New Granada (present-day Colombia) between 17801783. The reforms affected creoles (descendants of Spaniards born in the colonies), Indians, blacks and mestizos (the offspring of European and Indian unions), as well as other mixed-blood groups (castas). Creoles, in particular, felt deeply humiliated by the fact that Spanish-born subjects, even those with a lower social background and education, could enjoy the employment opportunities and social status denied to them. High-rank posts (whether civil, military or ecclesiastical) were now filled almost exclusively by Peninsular Spaniards ('españoles europeos'), a fact that tightened the already difficult social coexistence between the two groups. The restrictions on commerce (which was controlled by state monopolies) and the demands on agriculture, mining and industry were also a widespread source of frustration. ${ }^{1}$

\footnotetext{
${ }^{1}$ John Leddy Phelan, The People and the King. The Comunero Revolution in Colombia, 1781 (Madison, WI: The University of Wisconsin Press, 1978); Scarlett O’Phelan Godoy, Rebellions and Revolts in Eighteenth Century Peru and Upper Peru (Vienna: Böhlau Verlag, 1985); Peter Michael McKinley, Pre-revolutionary Caracas: Politics, Economy and Society 1777-1811 (Cambridge: Cambridge University Press, 1985); George Reid Andrews, 'Spanish American Independence: A Structural Analysis', Latin American Perspectives 12 (1985): 105-32; David A. Brading, 'Bourbon Spain and Its American Empire', in Colonial Spanish America, ed. Leslie Bethell (Cambridge: Cambridge University Press, 1987), 112-62; John Lynch, Bourbon Spain, 1700-1808 (Oxford: Basil Blackwell, 1989); John R. Fisher, Allan J. Kuethe and Anthony McFarlane, eds., Reform and Insurrection in Bourbon New Granada and Peru (Baton Rouge: Louisiana State University Press, 1990); Margarita Garrido, 'América y España en el concierto de naciones', in Historia de América Latina, Vol. 3, El sistema colonial tardío, ed. Margarita Garrido (Quito: Universidad Andina Simón Bolívar, Libresa, 2001), 23-58; Manuel Lucena Giraldo, 'The Limits of Reform in Spanish America', in Enlightened Reform in Southern Europe and its Atlantic Colonies, c. 1750-1830, ed. Gabriel Paquette (Farnham: Ashgate Publishing, 2009), 307-320.
} 
Such a discontent was to be articulated in a revolutionising plan of action by the ex-Jesuit Juan Pablo Viscardo y Guzmán, himself a victim of the absolutist policies of the Spanish monarch. Indeed, the Crown's decision in 1767 to expel the Jesuits from all its territorial domains marked the end of Viscardo's early novitiate in his native Peru and his forced exile to the Italian Peninsula. He was born in Pampacolca (Arequipa) in 1748 , and was never to return to the Spanish dominions. Not much of his personal life has come down to us, although we do know that he lived in Italy for several years before moving to London, grief-stricken by poverty, ill-health and a bitter feeling of anger due to the reluctance of the Spanish authorities to give him legal access to his lost patrimony in Peru. Because of the expulsion of the Jesuits and the evils he had to endure thereof, it is clear that Viscardo had a political as much as a personal motive in designing a project that would cut the colonial ties between Spain and the New World. Although he had no military credentials on which to base such an ambitious plan, his intellectual formation as a former Jesuit and his commitment to the cause for independence seem to have been powerful enough to attract the attention of the British government, initially through diplomatic contacts in Italy and later through direct negotiations with the Foreign Office in London, where he spent his final years. ${ }^{2}$

\footnotetext{
${ }^{2}$ Miguel Batllori, S. J., El abate Viscardo. Historia y mito de la intervención de los jesuitas en la independencia de Hispanoamérica (Caracas: Instituto Panamericano de Geografía e Historia, 1953); César Pacheco Vélez, 'Tras las huellas de Viscardo y Guzmán. Estudio preliminar', in Juan Pablo Vizcardo y Guzmán, Colección Documental de la Independencia del Perú, ed. César Pacheco Vélez (Lima: Comisión Nacional del Sesquicentenario de la Independencia del Perú, 1975), XLV-CXXVIII; Merle E. Simmons, Los escritos de Juan Pablo Viscardo y Guzmán, precursor de la independencia hispanoamericana (Caracas: Universidad Católica Andrés Bello, Instituto de Investigaciones Históricas, 1983); David A. Brading, introduction to Juan Pablo Viscardo y Guzmán, Letter to the Spanish Americans. A Facsimile of the Second English Edition (London, 1810) (Providence, Rhode Island: The
} John Carter Brown Library, 2002), 3-59; Karen Stolley, 'Writing Back to Empire: Juan Pablo Viscardo y Guzmán's “Letter to the Spanish Americans”, in Liberty! Égalité! Independencia!: Print Culture, 
The emancipation of Spanish America had enormous political and commercial appeal to the British who, moreover, did not enjoy a particularly friendly relationship with the Spanish Crown. Knowing this, Viscardo took much pain in delineating the economic advantages that a British military intervention backed by the creole elite would bring to both parties (the issue of independence was essentially presented to the British Government in terms of a commercial enterprise from which Britain had much to gain, a point that would be reiterated by several other creole ideologues in the years to come). ${ }^{3}$ In the end, however, the volatile nature of Anglo-Spanish diplomacy made Viscardo's plan impractical. In fact, had it not been for Francisco de Miranda, the Precursor of the Independence of Venezuela who published the Letter in London after Viscardo's death in February 1798, the ex-Jesuit's name would probably have been obliterated from history. ${ }^{4}$

Enlightenment, and Revolution in the Americas, 1776-1838, ed. David S. Shields and Mariselle Meléndez (Worcester, MA: American Antiquarian Society, 2007), 117-131; Mónica Elsa Scarano, 'La Carta a los españoles americanos, de Juan Pablo Viscardo. Aportes para el estudio del siglo XVIII hispanoamericano', América sin nombre 18 (2013):149-161; Karen Racine, 'Loss, Loneliness and Liberation: Juan Pablo Viscardo y Guzmán and the Formation of American Identity in Exile (17681798)', Dieciocho 39/1 (2016): 129-52.

${ }^{3}$ Racine, 'Loss, Loneliness and Liberation', 134. For a survey of Spanish American nonconformist political writing during the period, see Pensamento político de la emancipación 1790-1825, ed. José Luis Romero and Luis Alberto Romero, 2 vols (Caracas: Biblioteca Ayacucho, 1985).

${ }^{4}$ On Miranda, see William Spence Robertson, The life of Miranda, 2 vols (Chapel Hill, NC: The University of North Carolina Press, 1929); Karen Racine, Francisco de Miranda: A Transatlantic Life in the Age of Revolution (Wilmington, DE: Scholarly Resources, 2003); Carmen L. Bohórquez Morán, Francisco de Miranda. Precursor de las Independencias de la América Latina, 3rd ed. (Caracas: El Perro y la Rana Ediciones, 2006); John Lynch, 'Francisco de Miranda: The London Years', in Francisco de Miranda: Exile and Enlightenment, ed. John Maher (London: Institute for the Study of the Americas, 2006), 22-53; Manuel Lucena Giraldo, Francisco de Miranda: la aventura de la política (Madrid: Editorial EDAF, 2011). 
Miranda received the document (together with several other manuscripts which Viscardo had prepared for British officials) from Rufus King, who was then Minister of the United States in London. Discerning its value as a poignant piece of anti-Spanish propaganda, Miranda hastened to publish the Letter in French, the language in which Viscardo had written most of his papers. ${ }^{5}$ This was followed by Spanish and English translations of the work, clearly with the aim of reaching a wide readership both in Britain and the Americas. Miranda's appreciation of the Letter as a rhetorical tool in the ideological struggle for independence can be gauged by the fact that he took with himtogether with a printing press - several copies of the Spanish translation to be distributed among the native population in his first attempt to liberate Venezuela in 1806. Like Viscardo, the various independence projects conceived by Miranda from 1790 to 1806 relied on the assumption that popular support for their cause would be secured in the colonies through ideological propaganda, a tactic that would ignite the already predisposed sentiments of Spanish Americans against their cruel oppressors. ${ }^{6}$ Viscardo, in particular, believed that the dissemination of a South American patriotic fervour would lead to an unyielding quest for national sovereignty. ${ }^{7}$ Although he may have envisioned the future development of a mestizo society in Peru that would bring together its ethnic differences, he saw the emancipation process essentially as the result

\footnotetext{
${ }^{5}$ Lettre aux Espagnols-Américains (Philadelphie (sic), 1799). The false imprint of Philadelphia was intended to avoid a diplomatic embarrassment to the British authorities; see Pacheco Vélez, 'Tras las huellas de Viscardo', LXXIV. On the dissemination of the Letter and its various editions, see Batllori, El abate Viscardo, 148-59.

${ }^{6}$ See Miranda to William Pitt, 8 September 1791, together with his 'Proclama a los Pueblos del Continente Américo-Colombiano', in América espera, ed. J. L. Salcedo-Bastardo (Caracas: Biblioteca Ayacucho, 1982), 110-14 and 356-58 respectively. Robertson, The life of Miranda, 1: 166-68; José Gil Fortoul, Historia Constitucional de Venezuela, 2nd edn, 3 vols (Caracas: Parra León Hermanos, 1930), 1: 147, 150; Bohórquez Morán, Francisco de Miranda, 257-58.

${ }^{7}$ Robertson, The Life of Miranda, 1: 195.
} 
of creole support for a British invasion. Inevitably, this excluded a de facto participation of Indians and other subaltern groups from its future politico-administrative organization. It could not be otherwise given his idiosyncratic make-up. David Brading puts it very well when he observes:

Viscardo belonged to a generation and a social milieu in which the term "Americans" had yet to be applied to describe all the inhabitants of the New World. [...] When he addressed his Letter to the American Spaniards, he thus had in mind the Peruvian equivalents of the European "nobility, bourgeoisie and clergy". 8

Viscardo's lack of commitment to a full-fledged doctrine of popular sovereignty as it was understood in modern political theory (particularly in French and AngloAmerican thought) is quite evident. ${ }^{9}$ Miranda, on the other hand, sought to appeal to a larger sector of the Venezuelan population, thereby creating mistrust among the creole

\footnotetext{
${ }^{8}$ Brading, introduction to Juan Pablo Viscardo y Guzmán, 37. $C f$. 'Esbozo político sobre la situación actual de América española' [Political sketch on the present state of Spanish America], in Juan Pablo Viscardo y Guzmán, Obra completa, ed. Percy Cayo Córdova, trans. Ana María Juilland (Lima: Banco de Crédito del Perú, 1988), 81. See Luis Navarrete Orta, 'Viscardo y Bolívar: dos momentos del proyecto emancipador latinoamericano', in Beatriz González Stephan et al., Esplendores y miserias del siglo XIX: cultura y sociedad en América Latina (Caracas: Monte Ávila Editores, 1995) 129-30; Luis Hachim Lara, 'La colonia y la colonialidad en la “Carta dirigida a los españoles americanos” del abate Viscardo', Revista de Crítica Literaria Latinoamericana, 67 (2008): 58; Beatriz Pastor Bodmer, Cartografías utópicas de la emancipación (Madrid and Frankfurt am Main: Iberoamericana, Vervuert, 2015), 172-73.

9 'The appeal to the Hispanic tradition — not a rejection of Spain but the adoption of an alternative Spanish tradition - represented their defence against the creeping influence of revolutionary doctrines of sovereignty of the "people" or "nation"”. Brian R. Hamnett, 'Process and Pattern: A Re-Examination of the Ibero-American Independence Movements, 1808-1826', Journal of Latin American Studies, 29/2 (1997): 304.
} 
elite with regard to the social consequences of what were considered to be dangerous and unacceptable democratic principles. ${ }^{10}$ However, both Viscardo and Miranda were fundamentally wrong about the alleged support of the inhabitants of the colonies for their independence projects, a miscalculation that would prove fatal in Miranda's first expedition of 1806. Indeed, it might not be unfair to criticise Miranda—who did have military credentials - for failing to note that military success had to precede ideological indoctrination. $^{11}$

\section{The question of racial heterogeneity}

Creole and mestizo complaints about the Spanish administration throughout the colonies had been frequent in the last few decades of the eighteenth century. For the most part, their purpose was to call the attention of the Crown to the harsh conditions the population was forced to endure due to high taxation, the lack of commercial opportunities with other nations, and the corrupt practices of some Spanish officials in the administration of the colonies. Yet, they did not openly call for a revolution that

\footnotetext{
10 'Que los buenos e inocentes indios, así como los bizarros pardos, y morenos libres crean firmemente, que somos todos conciudadanos, y que los premios pertenecen exclusivamente al mérito y a la Virtud en cuya suposición obtendrán en adelante infaliblemente, las recompensas militares y civiles, por su mérito solamente'. Miranda, 'Proclama a los Pueblos del Continente Américo-Colombiano', in América espera, 356; my italics. Miranda's democratic principles, however, need to be taken with a pinch of salt. See Robertson, The life of Miranda, 1: 47, 50, 57; 2: 237-38; Bohórquez Morán, Francisco de Miranda, 21821, 334-37; Racine, Francisco de Miranda, 219-20; idem, 'Francisco de Miranda y Thomas Jefferson: Vidas paralelas en el mundo atlántico', El mundo atlántico y la modernidad iberoamericana, 1750-1850, eds. Roberto Breña and Roberto González Manterola (Mexico: Historia 20/10, 2012), 183-195. On race and racism in Spanish America, see note 14 below.

${ }^{11}$ On the failure of Miranda's 1806 expedition to Venezuela, see James Biggs, The History of Don Francisco de Miranda's Attempt to Effect a Revolution in South America, in a Series of Letters (Boston:
} Oliver and Munroe, 1808), Letter XXVI, 248-78 (esp. 255-57); Malcolm Deas, 'Some Reflections on Miranda as Soldier', in Francisco de Miranda: Exile and Enlightenment, ed. Maher, 77-87. 
would bring about their political independence. As far as the creole elite was concerned, their demands would have been appeased with the securement of a more balanced position vis-à-vis Peninsular Spaniards, a review of commercial, agricultural and industrial policies which badly affected the population and, more generally, a wider access to science and education (the old-fashioned, scholastic character of higher education and the repressive role of the Inquisition regarding the dissemination of enlightened ideas was a frequent lament among creoles). ${ }^{12}$ As a contemporary quiteño intellectual put it:

To tell the truth, gentlemen, we are destitute of education, we lack the means to prosper, we are not moved by the incentive of honour, and good taste is far removed from us.

We live in the grossest ignorance and the most deplorable misery. ${ }^{13}$

Still, an overthrow of the colonial system was not generally seen as a desirable option; far from it, large sectors of the population viewed its authorities as guarantors of their property and status. In Peru, the Tupac Amaru rebellion had shown that these could not be taken for granted, and similar events in other parts of the continent and the

\footnotetext{
12 Javier Ocampo López, El proceso ideológico de la emancipación (Medellín: La Carreta Editores, Universidad Pedagógica y Tecnológica de Colombia, 2010), 19-269.

${ }^{13}$ Eugenio de Santa Cruz y Espejo, 'Discurso sobre el establecimiento de una Sociedad Patriótica en Quito' (1789), [Speech on the establishment of a Patriotic Society in Quito], in Pensamento politico de la emancipación, ed. Romero, 1: 44; my translation. For an eighteenth-century evaluation of the Bourbon reforms and their limitations, see Premoniciones de la Independencia de Iberoamérica. Las reflexiones de José de Ábalos y el Conde de Aranda sobre la situación de la América española a finales del siglo XVIII, ed. Manuel Lucena Giraldo (Madrid: Fundación Mapfre Tavera, Ediciones Doce Calles y Secretaría de Coperação Ibero-Americana, 2003).
} 
Caribbean had convinced the creole elite that nothing could be more disastrous for their existence than the absence of the colonial order which, they believed, was the only force capable of containing the social and ethnic war that would otherwise erupt in Spanish America. Events in Mexico in 1810 - the Hidalgo Revolt — proved this to be the case. For the coastal regions of Venezuela and New Granada — where large numbers of black slaves and free men of colour were to be found - the black slave revolt in the rich French colony of Saint-Domingue (present-day Haiti) during the last decade of the eighteenth century provided a grave cause of concern, for it resulted in the extermination of the French colonists and the subversion of the colonial order that had been formally implanted in the island since $1697 .{ }^{14}$

Viscardo's Letter, then, begins with a call to the patriotic sentiment of all Spanish Americans to assume their historical responsibility as an independent nation: 'The New World is our country ['notre patrie', 'nuestra patria']; its history is ours' (63). ${ }^{15}$ The proximity of the third centenary of the Discovery of the New World-he argues - should be an opportunity to reflect on the experience of colonial rule and the

\footnotetext{
${ }^{14}$ John Lynch, The Spanish American Revolutions, 1808-1826 (New York: W. W. Norton, 1973), 19-24, 28-29; Jorge I. Domínguez, Insurrection or Loyalty. The Breakdown of the Spanish American Empire (Cambridge, MA: Harvard University Press, 1980), 28-45; Kenneth J. Andrien, Andean Worlds: Indigenous History, Culture, and Consciousness Under Spanish Rule, 1532-1825 (Alburqueque:
} University of New Mexico Press, 2001), 202-32; Aline Helg, Liberty and Equality in Caribbean Colombia, 1770-1835 (Chapel Hill: The University of North Carolina Press, 2004), 42-120; George Reid Andrews, Afro-Latin America, 1800-2000 (Oxford: Oxford University Press, 2004), 11-52; Alfonso Múnera, Fronteras imaginadas. La construcción de las razas y de la geografía en el Siglo XIX colombiano (Bogotá, Editorial Planeta, 2005); Marixa Lasso, Myths of Harmony: Race and Republicanism During the Age of Revolution, Colombia 1795-1831 (Pittsburgh, PA: University of Pittsburgh Press, 2007), 16-33.

${ }^{15}$ I quote from the facsimile of the second English edition of 1810. All subsequent citations are to this edition. A facsimile of the original French version of the Letter is reproduced in Obra completa, ed. Percy Cayo Córdova, 223-65. For a facsimile reproduction of the first Spanish edition, see ibid., 271-314. 
political alienation it had brought to its inhabitants. Yet, the 'country' to which Viscardo refers constituted a vast territory occupied by a multiplicity of ethnic communities separated from each other by harsh geographical and historical circumstances. Thus, his use of the term bypasses the complexities of a heterogeneous milieu where deep cultural, social and racial differences made it difficult to define the essence of the human conglomerate that was supposed to represent the 'nation' and its 'people'. ${ }^{16}$ In point of fact, eighteenth-century creoles identified themselves as part of the Spanish nation: they were Spaniards born in the colonial territories. Hence, the adjective 'americanos' did not imply a separate sense of nationhood, it simply qualified their origin. It was mainly with the emergence of the independence movements in the $1810 \mathrm{~s}$ that creoles and other social groups began to identify themselves simply as 'americanos', thus rejecting their former allegiance to the Spanish Crown. Although in ‘Esbozo político sobre la situación actual de América española’ [Political sketch on the present state of Spanish America], Viscardo seems to envisage the future development of a mestizo society in Peru that will reconcile its ethnic differences, there is no direct connection between Viscardo's call for patriotism and the consolidation of new national identities in Spanish America after independence. ${ }^{17}$ Viscardo does not tackle this issue

\footnotetext{
${ }^{16}$ Such terms were in the process of acquiring the new political character forged by national romanticism in the nineteenth century. See René Salinas Meza, 'Población, poblamientos y mestizajes. Una aproximación al último siglo colonial', El sistema colonial tardío, ed. Garrido, 168-72; José Carlos Chiaramonte, Nación y Estado en Iberoamérica: el lenguaje político en tiempos de las independencias (Buenos Aires: Editorial Sudamericana, 2004), 27-57.

17 'Es así como esta raza numerosa, tan valiente como robusta e inteligente, ubicada entre los blancos y los indios, es el eslabón más fuerte que une a estas dos clases en una misma sólida masa de Sociedad'. Juan Pablo Viscardo y Guzmán, Obra completa, ed. Percy Cayo Córdova, trans. Ana María Juilland (Lima: Banco de Crédito del Perú, 1988), 85. See Miguel Maticorena Estrada, 'Nación y guerra de castas en Juan Pablo Viscardo', in Juan Pablo Viscardo y Guzmán. El hombre y su tiempo (1748-1798), 3 vols (Lima: Fondo Editorial del Congreso de la República del Perú, 1999), 2: 176-212; Gonzalo Portocarrero
} 
here because the kind of revolutionary political entity he is thinking of stands for a specific social group: the creole elite and its economic interests, with which he wholeheartedly identified himself. This point is made clear in a letter he wrote in 1781 to the British Consul at Legorno, where he declares his conviction about the 'natural' superiority of the white population as well as his own suitability for leadership should the British Government back his proposal for a foreign military intervention in Peru:

I would not wish Your Honour to think that these classes [Indians, creoles and mestizos] act separately from each other but rather that they constitute a political body in which the creoles $[\ldots]$ have the first place, the mixed classes the second, and the Indians the last. In addition, my knowledge of the habits, traditions and prejudices of these peoples puts me in an advantageous position. The fact that I belong to a distinguished family from Arequipa where I have substantial assets, together with my long residence in Italy, would allow me to influence the opinion of my compatriots. Being a Jesuit and a creole, nobody would be less contrary than me to the new government nor less united to its interests. I can confidently assert that there are probably few men among the American Jesuits better disposed for the task than myself. ${ }^{18}$

In the same document, Viscardo suggests that the creoles had effectively become the protectors (if not the future redeemers) of the destitute Indians: 'Far from being hated,

Maisch, 'Juan Pablo Viscardo y Guzmán: entre la lucidez impotente y la ilusión movilizadora', ibid., 273-306.

${ }^{18}$ Viscardo to John Udny, 30 September 1781, Obra completa, 9, 11; my translation. There is a striking similarity between Viscardo's defence of the creole elite and the arguments presented by Simón Bolívar in a journalistic article he is thought to have written in 1815 for the Royal Gazette in Jamaica; see Simón Bolívar, Doctrina del Libertador, ed. Manuel Pérez Vila (Caracas: Biblioteca Ayacucho, 1985), 75-79. In both cases, their aim is to reassure the civilized nations of the world that the conditions for independence, international free trade, and economic prosperity in the Spanish colonies were ripe, and that this enterprise could be secured under creole leadership. 
the creoles were respected and loved by many. The Indians used to call them Viracocha, which was the name of one of their rulers. ${ }^{19}$ Clearly, this is an attempt to legitimize creole hegemony by claiming the absolute moral and intellectual superiority of the white elite over the rest of the population, one which is ready to succumb to the rule of its new master. Consider also the following statement, which is contemporaneous with the Letter to the Spanish Americans:

Since the creoles are the soul and first mover of the Spanish colonies (for the same reason that the nobility, the bourgeoisie and the clergy occupy the first place in all European states), it was essential to examine their character given the decisive influence they have over the other classes. ${ }^{20}$

In the Letter to the Spanish Americans, however, Viscardo makes no mention of black slavery, not even on the grounds of human compassion. As a matter of fact, the terms 'slavery' and 'enslavement' appear only as metaphorical descriptions of the oppression of the creoles under Spanish rule, a rhetorical device that would become commonplace in Patriot discourse two decades later. In 'Esbozo político sobre la situación actual de América española', Viscardo even finds himself at odds in describing the black population of Spanish America, whose culture, values and traditions he probably ignored. ${ }^{21}$ Despite his remarks about the sad condition of Indians

\footnotetext{
${ }^{19}$ Obra completa, 13. Viracocha is in fact the name of the creator god in Inca mythology.

20 'Esbozo político sobre la situación actual de América española', Obra completa, 81; my translation (italics added).

21 'Los negros y mulatos de los asentamientos europeos son bastante conocidos como para detenerse a describirlos. Si hay alguna diferencia con los de las colonias españolas, se la puede inferir de lo que se ha dicho, con respecto de las islas de esta nación. [...] Se sabe que los mulatos son valientes e inteligentes, y puedo agregar que generalmente, sienten tanto apego por los españoles criollos, como aversión por los chapetones.' Obra completa, 86-87.
} 
and mestizos, and his apparent praise of mulattoes, it is obvious that the question of political independence was for him something that pertained creole interests alone rather than the vast social strata that made up the bulk of the Spanish American population. Within such an obtuse worldview, the well-being of blacks and mulattoes was a matter of secondary importance. The idyllic picture presented by Viscardo in his writings, therefore, plays down the possibility of racial conflict in Spanish America and underscores the capacity of the white elite to lead the destiny of the future independent nation.

\section{Viscardo's response to Spanish tyranny}

In the Letter to the Spanish Americans Viscardo reflects on the relation between Spain and the New World from a radical creole nationalist perspective. For the American Spaniards, he maintains, the roots of the nation should be identified with the motherland ('the place where one is born'), not with the distant, transatlantic metropolis. ${ }^{22}$ This premise, which is based on an emotional allegiance to the homeland, allows Viscardo to present a defence of what he considers to be the creoles' indisputable natural rights in the colonies. Paradoxically, these go back to the Conquistadors who sacrificed their personal possessions and security for the glory of the Spanish Empire (note that

\footnotetext{
${ }^{22}$ Eric J. Hobsbawm, Nations and Nationalism Since 1780, 2nd ed. (Cambridge: Cambridge University Press, 2012), 15. See Mónica Quijada, ‘QQué Nación? Dinámicas y dicotomías de la nación en el imaginario hispanoamericano del siglo XIX', in Imaginar la Nación, ed. François-Xavier Guerra and Mónica Quijada (Münster: AHILA, Cuadernos de Historia, 1994), 19-31; François-Xavier Guerra, Modernidad e independencias. Ensayos sobre las revoluciones hispánicas (Madrid: Ediciones Encuentro, 2009), 390-466; Gabriel Entin, 'El patriotismo americano en el siglo XVIII: ambigüedades de un discurso político hispánico', in Las independencias hispanoamericanas: un objeto de historia, ed. Véronique Hébrard and Geneviève Verdo (Madrid: Casa de Velázquez, 2013), 19-33.
} 
Viscardo makes no mention of the indigenous people of Peru whose rights had been seized by the Spaniards and their direct descendants). ${ }^{23}$ In return for their sacrifices, he argues, the Spaniards expected to be rewarded with land and other royal privileges granted for their exclusive enjoyment, as dictated by Spanish medieval tradition. Viscardo accuses the Spanish monarchy for not respecting this contract:

Let us consult our annals for three centuries; they discover to us the ingratitude and injustice of the Court of Spain, and its treachery in not fulfilling the engagements contracted at first with the great Columbus, and afterwards with the other conquerors, who gave to it the empire of the New World, on conditions solemnly stipulated; we shall see the offspring of those magnanimous men branded with scorn, and pursued by the hatred which has calumniated, persecuted and ruined them. (69)

Viscardo's main argument in defence of emancipation is essentially of a juridical nature. Its aim is to accuse the Spanish monarch of exercising a tyrannical rule over his colonial subjects, a despotism that nullifies its own legitimacy according to the very principles upon which the king's authority was based: 'Every law which opposes itself to the general good of those for whom it is made, is an act of tyranny' (64). Viscardo's thought is firmly based on the idea—-held both by late scholastic and early modern European political thinkers - that the king derives his power not from God but from the people, with whom a pact of reciprocity and mutual obligations is made for the sake of the common good. In the Spanish juridical tradition, this doctrine had been

\footnotetext{
23 On the conflict between creole interests and Indian rights, see Domenico Losurdo, Liberalism: A Counter-History, trans. Gregory Elliot (London: Verso, 2011), 148-49.
} 
maintained by the Jesuit Francisco Suárez (1548-1617) who defended the legitimate right of the people to depose their king whenever the purity of the pact was violated and replaced by the will of a tyrant. ${ }^{24}$

In addition, Viscardo draws attention to the commercial regulations introduced by the Bourbon reforms. He criticises the high cost of goods and raw materials imported from Spain (the production, trade and manufacture of certain commodities in the colonies was not allowed by the Crown), while export products were sold at very low prices. Viscardo also highlights the detrimental effects of Spanish monopolies. Such practice, he says, had led to commercial speculation and the imposition of heavy taxes, all of which placed an intolerable burden upon the inhabitants of the New World. For Spanish American merchants this policy could only represent a direct attack on their economic interests and those of the colonies at large, forcing them to implement commercial practices that took no notice of their real needs and prosperity:

Since men began to unite in society for their mutual interest, we are the only people whom government has compelled to provide for our wants at the highest price possible; and to part with our productions at the lowest price. In order that this violence should have the most complete success, we have been cut off, as in a besieged town, from every channel through which we might have been able to obtain from other nations, at moderate prices and by fair exchanges, the commodities which we wanted. The imposts of government, the fees of officers, the avarice of the merchants empowered to exercise conjointly the most unbridled

\footnotetext{
${ }^{24}$ Manuel Giménez Fernández, 'Las doctrinas populistas en la independencia de Hispano-América', Anuario de Estudios Americanos 3 (1946): 519-665; Pacheco Vélez, 'Tras las huellas de Viscardo y Guzmán', XCVII-CV; Rafael Gómez Hoyos, La revolución granadina de 1810: ideario de una generación y de una época 1781-1821, 2 vols (Bogotá: Editorial Kelly, 1982), 1: 75-90; Anthony Pagden, Spanish Imperialism and the Political Imagination (New Haven: Yale University Press, 1990), 117-21. On Viscardo and English liberal thought; see Racine, Francisco de Miranda, 145.
} 
monopoly, - all bearing the same way, scarcity no longer left a choice to the purchaser; and as this mercantile tyranny might force us to have recourse to our industry to supply our wants, the government took care to enchain it. (65)

Viscardo is also critical of the abuses of certain officials of the colonial administration whom he holds responsible for the economic ruin of Indians and mestizos. The practice in question, known as 'repartimiento de comercio' [distribution of merchandise], forced the native population to consume goods they did not need or, in any case, could not afford. Because they lacked the means to purchase what was on offer, Indians contracted debts they could not pay back. This, in turn, exposed them to the abuse of Spanish authorities who would demand unreasonable forms of compensation, including the production of marketable commodities with which to repay their debt. ${ }^{25}$

Having considered the pernicious effects of Bourbon policy in Spanish America, Viscardo reiterates his critique of the legal foundations of colonial rule. He does so by appealing to the political institutions of medieval Spain in which the system of the Cortes (the Spanish representative assembly) embodied the will of the nation. Once again, his purpose is to show that within Spanish law opposition to tyranny and absolutism constituted a legitimate right of the people. Since Bourbon absolutism was

\footnotetext{
${ }^{25}$ David Brading, The First America: The Spanish Monarchy, Creole Patriots and the Liberal State 1492-1866 (Cambridge: Cambridge University Press, 1991), 470-71; Andrien, Andean Worlds, 202-04. In 'Esbozo político sobre la situación actual de América española', Viscardo describes the system as 'the source of the most abominable extortions'. See Obra completa, 83 (my translation). The system of repartimiento de comercio is also mentioned in 'Ensayo histórico sobre los disturbios en América Meridional en el año 1780' [Historical essay on the troubles of South America in the year 1780], which discusses the Tupac Amaru rebellion. Unfortunately, Viscardo provides little information about the nature of the abuses; see Obra completa, 45.
} 
contrary to the true spirit of the Spanish monarchy, he affirms, the colonies had every right to oppose it:

Our ancestors, in re-establishing the kingdom and its government, thought only of guarding against the absolute power to which our kings have always aspired. With this design, they concentred the supremacy of justice, and the legislative powers of peace, war, subsidies, and the granting of monies, in the Cortes which represented the different classes of the nation, and were to be the depositaries and guardians of the rights of the people. (73)

After dealing with what he sees as a radical failure of the Crown to administer its possessions in the New World in an equitable manner, Viscardo turns his attention to a more personal concern: the Imperial decree that sealed the fate of five thousand Jesuits throughout the Spanish territories in 1767: 'Five thousand Spanish citizens [...] have been stript (sic) by the government of all their rights, without any accusation, without even the forms of justice, and in the most arbitrary manner' (76). The expulsion and ruin of the Jesuits, he affirms, had no other cause but the Crown's greed and envy at their wealth (78). ${ }^{26}$

The Society of Jesus had indeed played a powerful economic role in the Spanish colonies. During the seventeenth and eighteenth centuries, the Jesuits were well known for their success in creating autonomous indigenous communities. These missions, or 'reducciones de indios' [Indian reductions], were market-oriented in nature and

\footnotetext{
${ }^{26}$ See Jeffrey Klaiber, 'Los jesuitas expulsos (Clavijero, Molina y Viscardo y Guzmán): historia, evolución y revolución', in Milena Koprivitza Acuña (ed.), Ilustración en el mundo hispánico: preámbulo de las independencias (Tlaxcala: Instituto Tlaxcalteca de la Cultura, 2009), 183-200.
} 
included a large and well-organised workforce capable of yielding vast revenues, mostly from agricultural products. In urban areas, on the other hand, the Jesuits contributed enormously to the advancement of science and education. According to historian Mariano Picón Salas, by 1700 the Jesuit Order was not only the foremost cultural organisation throughout Spanish America but also one of the strongest financial forces in the colonial world. ${ }^{27}$ Because of their advanced ideas in the realm of politics and government (as exemplified in the doctrines of Suárez and others), the Crown had long mistrusted the Jesuits; now, in the age of enlightenment, they had become its virtual enemy. ${ }^{28}$

As I have already mentioned, the reforms introduced by Charles III eliminated the privileges and opportunities Spanish Americans had enjoyed in the administration of the colonies at the beginning of the eighteenth century. In particular, the restrictions on high-rank administrative positions were seen as an act of aggression against the creole elite, who felt discriminated against:

Thus, whilst at court, in the armies, and in the tribunals of the monarchy, they lavish riches and honours upon foreigners of all nations, we alone are declared unworthy of them; we are declared incapable of filling, even in our own country, places which, in the strictest right, belong to us exclusively. (69; my italics)

\footnotetext{
${ }^{27}$ De la Conquista a la Independencia, 3rd ed. (Mexico and Buenos Aires: Fondo de Cultura Económica, 1958), 147

${ }^{28}$ See Magnus Mörner, The Political and Economic Activities of the Jesuits in the La Plata Region. The Hapsburg Era (Stockholm: Institute of Ibero-American Studies, 1953), 59-77; Magnus Mörner, ed., The Expulsion of the Jesuits from Latin America (New York: Knopf, 1965), 11-15; Lynch, Bourbon Spain, $280-84$.
} 
Viscardo's final appeal, therefore, is a call to the pride and courage of all American Spaniards to claim back what truly 'belongs' to them. He contends that the distance that separates Spain from its rich and vast colonies requires the creation of autonomous forms of government that can look after the real needs and interests of its people:

Nature has separated us from Spain by immense seas. [...] We have essential need of a government which would be in the midst of us, for the distribution of benefits, - the object of the social union. (81-82)

More importantly, he argues, Spanish Americans should observe the example of the English colonies in North America who, in fighting for their freedom, gave other nations a lesson on the exercise of civic virtue and liberty. Not to follow their steps in the path to political autonomy meant not only to miss the historic opportunity that other countries had seized for themselves, but also an act of indolence which future generations would not forget. Implicitly, Viscardo alludes here to eighteenth-century pseudo-scientific descriptions of the New World (including the racialist theories of George-Louis Leclerc Buffon, Corneille de Pauw and others), that stigmatised Spanish American peoples as inferior races. ${ }^{29}$ This negative perception (contested among others by the Benedictine friar Benito Jerónimo Feijóo and the Mexican ex-Jesuit Francisco

\footnotetext{
${ }^{29}$ Antonello Gerbi, The Dispute of the New World: The History of a Polemic, 1750-1900, trans. Jeremy Moyle (Pittsburgh: University of Pittsburgh Press, 1973).
} 
Javier Clavijero) constituted a serious indictment against creoles, for it questioned their capacity to govern civilized and industrious societies. ${ }^{30}$ Were Spanish Americans ready to face this historical challenge and prove that they, too, were capable of acquiring moral and political virtues? Other aspects of his argument may be based on juridicophilosophical principles, but the idea that Spanish Americans will carry the guilt of their inaction has a special moral-psychological significance because it appeals directly to their conscience:

The valour with which the English colonies of America have fought for the liberty, which they gloriously enjoy, covers our indolence with shame; we have yielded to them the palm with which they have been the first to crown the New World by their sovereign independence. [...] Our descendants will load us with imprecations, when, biting in vain the curb of slavery — of a slavery which they shall have inherited, they will remember the moment in which to be free, we had only to will it. (83-84)

However, set against English colonial rule in North America — where civil rights and liberties had been enjoyed - Spanish Americans had not developed a sense of civic responsibility that would nourish and protect the general interests of the nation ('nation' in the broad sense of a people's shared cultural and historical patrimony that shapes a

\footnotetext{
${ }^{30}$ Batllori, El abate Viscardo, 165-71. For a discussion of the main issues, see Brading, The First America, 422-64; Manuel M. Marzal, S. J., 'Viscardo y el americanismo del exilio jesuítico', in Juan Pablo Viscardo y Guzmán (1748-1798). El hombre y su tiempo, 2: 125-52. For Viscardo's own critique, see 'Esbozo político sobre la situación actual de América española', Obra completa, 72-81.
} 
common political goal). ${ }^{31}$ This became evident once the desire for political autonomywhich started as a protective measure against the Napoleonic invasion of Spain in 1808 - turned into regional confrontation almost everywhere in Spanish America. Thus, reflecting on the causes of the political crisis that took hold of the colonies in the 1810s, Simón Bolívar would be forced to conclude:

Until our patriots acquire those talents and political virtues which distinguish our North American brethren, I am very much afraid that our popular systems, far from being favourable to us, will occasion our ruin; for, unhappily for us, these good qualities appear to be very distant from us in their requisite perfection. [...] Shall we be able to maintain, in its true equilibrium, the difficult charge of a republic? Is it to be conceived, that a people but just released from their chains can fly at once into the sphere of liberty? Like Icarus, their wings would be loosened, and they would refall into the abyss. Such a prodigy is inconceivable, in fact never seen; consequently, there is no reasonable argument which can bear us out in this expectation. ${ }^{32}$

The notions of civic duty and responsibility were generally ineffective because Spanish colonial society had been built upon the premise of social and racial difference. This resulted in the marginalisation of large sectors of the population and their consequent inability to represent themselves as being part of a political community that

\footnotetext{
${ }^{31}$ José Carlos Chiaramonte, Fundamentos intelectuales y políticos de las independencias (Buenos Aires: Editorial Teseo, 2010), 87-89, 110-16; Hamnett, 'Process and Pattern', 328.

32 'General Bolivar's (sic) Letter to a Friend, on the Subject of South-American Independence', The Jamaica Quarterly Journal and Literary Gazette 3/1 (1819): 169. This document, which came to be known as 'The Jamaica Letter', was written by the Liberator during his exile in the British colony in 1815. See John Lynch, Simón Bolívar: A Life (New Haven and London: Yale University Press, 2006), $91-97$.
} 
went beyond narrow regional interests and ethnic identities. However, the problem was not merely politico-administrative nor was it simply a question of blaming the Spanish absolutist government for the creoles' inability to organise the new republics in an orderly, peaceful and efficient way. There was also a fundamental flaw in the character of the Spanish American people - their unruliness, arbitrariness and personal ambition — which became clear in the years to come. ${ }^{33}$ Bolívar, who warned against these obstacles with astonishing precision, could not conceal his own scepticism regarding the success of the revolution even at the very moment in which he was preparing to embark on his first constitutional project: the Venezuelan Constitution of 1819, which would be the basis for the Constitution of 'Great' Colombia two years later. As he puts it there: 'The diversity of origins requires an infinitely firm and infinitely delicate touch to manage this heterogeneous society whose complex structure becomes dislocated, divided, and dissolved at the slightest alteration.' ${ }^{34}$

\section{Conclusion}

It is ironical that in the struggle for South American independence that would ensue some years after the publication of Viscardo's Letter, Peru would be the last territory to break the colonial ties with Spain, and this only because of the pressure of the military campaigns led by men such as Bolívar, José de San Martín, and Antonio José de Sucre against the dominant royalist stronghold. It was never easy for the Peruvian creole elite

\footnotetext{
${ }^{33}$ For an example of inefficient and corrupt bureaucratic practices during this period, see Ana Catalina Reyes Cárdenas, 'El derrumbe de la primera república en la Nueva Granada entre 1810-1816', Historia Crítica 41 (2010): 39-61.

${ }^{34}$ Simón Bolívar, 'The Angostura Address' (15 February 1819), in El Libertador: Writings of Simón, ed. David Bushnell, trans. Frederick H. Fornoff (Oxford: Oxford University Press, 2003), 39.
} 
(on which Viscardo had so much depended for his project) to take sides with the Patriot rebels nor to accept the ideals of democratic republicanism that begun to germinate in the colonies after 1810. If Viscardo spoke of the existence of a united Peruvian nation based on strong fraternal links between creoles, Indians and mestizos, this ultimately obeyed a purely political need: that of representing his native country as a harmonious and mature social body capable of conducting its own commercial and administrative undertakings under creole leadership. Yet, this presumed social concord was by no means a palpable reality nor had the Indians and mestizos ever consented to be ruled by the creole elite.

Of course, Viscardo was not a promoter of republican ideas. Like Miranda's first constitutional projects drafted in London, Viscardo's plans for emancipation included the instauration of a monarchical form of government, the only one that, in his opinion, would be appropriate to the character of the Spanish American people. ${ }^{35}$ But his design was out of touch with reality and would have hardly been accepted by the inhabitants had a British-backed expeditionary force reached the coasts of Chile and Peru, as he had initially planned. In 'Proyecto para independizar América Española' [Project for the Independence of Spanish America], Viscardo not only suggests the candid idea that Britain could become the guardian of a free Spanish America (a thought nourished by Miranda, Bolívar and other creole promotors of independence in the years to come), but

\footnotetext{
35 'Sólo los Príncipes pueden desempeñar verdaderamente el rol heroico de Libertadores. [...] La veneración que se tiene en América por todo aquello que lleva el sello de la Realeza; [...] el entusiasmo de tener un rey entre gentes que no tienen sino ideas monárquicas; [...] estas son unas cuantas razones que valen ejércitos y que, apartando todo competidor, elevarían sobre la base más sólida del voto universal dos grandes tronos sobre las dos partes de América'. 'Proyecto para independizar América Española', Obra completa, 25. See Entin, 'El patriotismo americano en el siglo XVIII', 28-32. On Miranda, see Robertson, The life of Miranda, 1: 223-31; Bohórquez, Francisco de Miranda, 323-50.
} 
also that the presence of a Royal Prince in the British naval expedition to liberate the colony would win the esteem and trust of the population, thereby guaranteeing its success. ${ }^{36}$

In the end, the process of emancipation was not to be aided by the 'altruistic' gesture of a foreign imperial power, nor did it result in the realisation of a utopian dream where free trade, wealth and industry could work together for the betterment of mankind, as the ex-Jesuit had hoped. ${ }^{37}$ While Viscardo's Letter may have stirred a sense of creole patriotism all the way from Mexico to Buenos Aires in the decade following his death, the political scruples of the ancien régime based on social privileges and racial distinctions were too strong to be dismantled by mere ideals of freedom, justice and equality. In effect, the Spanish colonies were formed by a heterogeneous and disjointed population; social and economic interests were strongly determined by class, race, and regional circumstances which did not always fuse together in a harmonious chord. Viscardo's patria was a beautiful idea scattered throughout the continent, but it was nowhere to materialise in a homogeneous and organic entity.

\footnotetext{
${ }^{36}$ Obra completa, 25, 38-39. See also Viscardo to Sir James Bland Burges, 15 September 1791, ibid., 419-20. In 'Esbozo político sobre la situación actual de América española' he recommends an alliance with England (101), and suggests that the Spanish Caribbean island of Puerto Rico could easily be annexed to the British Empire (104). At the same time, Viscardo warned about the imperialist ambitions of France which he perceived as a menace to the Spanish colonies; see 'Ensayo histórico sobre los disturbios en América Meridional en el año 1780’, Obra completa, 56.

37 'What an agreeable and affecting spectacle will the fertile shores of America present, covered with men from all nations exchanging the productions of their country against ours! [...] Thus would America unite the extremities of the earth; and her inhabitants, united by a common interest, would form one great family of brothers' (85). The idea is developed by Viscardo in 'La paz y la dicha del nuevo siglo' [The peace and happiness of the next century], Obra completa, 129-201. On this issue, see Fidel J. Tavarez, 'Viscardo's Global Political Economy and the First Cry for Spanish American Independence, 17671798', Journal of Latin American Studies, FirstView Article, 1-28. Available on CJO2015. doi:10.1017/S0022216X15001194 (last accessed 27 June 2016).
} 
Because of his idiosyncratic conception of natural law (which was based on political exclusion and social inequality), Viscardo's own thoughts about political participation were conceived along the very same hierarchical structures of the colonial regime he wanted to destroy. His vision of a monarchical form of government built on a rigidly stratified and racially heterogeneous society meant that effective political participation was ultimately restricted to the creole elite, whom Viscardo saw as the legitimate guarantor of social order and economic prosperity. 